\title{
Integrated GIS, Remote Sensing and Survey Data for Damage Assessment of Buildings in Tsunami Event, Ishinomaki City, Japan
}

\author{
Mohammad Reza Poursaber ${ }^{1,2 *}$, Yasuo Ariki² \\ ${ }^{1}$ Faculty of Civil, Water and Environmental Engineering, Shahid Beheshti University, Tehran, Iran \\ ${ }^{2}$ Graduate School of System Informatics, Kobe University, Kobe, Japan \\ Email: *poursaber@me.cs.scitec.kobe-u.ac.jp
}

Received 17 December 2015; accepted 23 April 2016; published 26 April 2016

Copyright (C) 2016 by authors and Scientific Research Publishing Inc.

This work is licensed under the Creative Commons Attribution International License (CC BY). http://creativecommons.org/licenses/by/4.0/

(c) (7) Open Access

\section{Abstract}

The 2011 Tsunami event in the eastern coastal area of Japan caused a huge amount of damages or devastations on buildings. To this date, several field surveys have been conducted which provide detailed information about inundation areas and building damage characteristics in attacking east coastal areas by this tsunami. In this study, building damage data of Ishinomaki city, with special attention to the plain coast affected area, are classified and analyzed using data surveyed by the Ministry of Lands, Infrastructure and Transportation of Japan (MLIT) for more than 52,000 structures. The classification includes information on six levels of damage, four types of building materials and damages due to tsunami inundation for each building material which are necessary information for an effective hazard mitigation. Notably, damage level percentage distribution of different building materials is plotted for different inundation depth ranges in several sets of figures. This graphic illustration not only shows a better resistant performance of Reinforced Concrete (RC) and steel buildings over wood or other buildings for all inundation depth ranges, but also can explain clearly the inundation-induced damage behavior for each building material as well as the threshold depth for each damage level. Moreover, this research contains an analysis of vulnerable areas due to the coastal topography and the geographical factors. Surveyed data provided by Geospatial information authority of Japan (GSI) that classifies Ishinomaki plain coast area into three classes are compared with the damage map produced using an Analytical Hierarchy Process (AHP) methodology in ArcGIS 10.2 environment. The influence of key geographical features on tsunami-induced building damage, notably Kitakami river and water canals flooding, is taken into account with respect to the weighting of factors. A good agreement produced building damage map with surveyed GSI data shows the power of a GIS tool based on the AHP approach for tsunami damage assessment. The results of this study are useful to understand the damage behavior of buildings with different structural materials located in coastal areas vulnerable to the tsunami

\footnotetext{
${ }^{*}$ Corresponding author.
}

How to cite this paper: Poursaber, M.R. and Ariki, Y. (2016) Integrated GIS, Remote Sensing and Survey Data for Damage Assessment of Buildings in Tsunami Event, Ishinomaki City, Japan. Journal of Geographic Information System, 8, 260-281. 


\section{disaster.}

\section{Keywords}

Building Material Characteristics, GIS, Remote Sensing, AHP, Tsunami Damage Map

\section{Introduction}

A natural disaster event that occurs in a populated area is a hazardous event that causes a huge amount of destruction and fatalities. A tsunami is one of these natural hazards which can harm human and properties vastly since it happens in an inhabited area. The 2011 Great east Japan, tsunami that attacked the east coast of Japan causes more than 400,000 buildings damaged or destroyed [1].

Unfortunately, in different human societies that are in danger of such natural disasters, people are engaging in developing infrastructure and building constructions seemingly without vulnerability assessment of hazards impact. Therefore, it is essential to improve our understanding of building damage characteristics and coastal topography due to a tsunami event. Then, it will be possible to prepare an initial vulnerability and damage assessments of a disaster event as a tool to reduce its damage to the community for an effective hazard mitigation [2]-[4]. Such mitigation of natural disasters becomes successful only with accurate and reliable information through building damage surveyed databank of previous hazardous events in an area together with spatial data of vulnerable areas.

Early studies provide discussions about the influence of building constructions material and the number of stories on the building resistance to tsunami inundation in several case studies using surveyed building damage data [5]-[7]. Moreover, several threshold depths as damage criteria for each different construction material against a range of tsunami inundation depths are accordingly suggested [8] [9].

It is shown by these studies that the RC or steel based constructions are stronger than wood or masonry based constructions for different inundation depth ranges through plotting of fragility curves in many case studies [10][16]. These results reflected the tsunami damage probability related to the building construction material, height and number of stories under different tsunami inundation depths. Instead of plotting fragility curves, we adopted a way to classify the MLIT surveyed damage data of Ishinomaki city for each building material and six damage levels based on their percentage amount under inundation depth range of 0 - $8.5 \mathrm{~m}$ with simple graphical schematics. These graphical illustrations are suitable for quick assessment of building damage based on the tsunami inundation map produced through a field survey and a Geographic Information System (GIS) software. Results not only show a better resistant performance of RC and steel buildings over wood or other buildings for all inundation depth ranges, but also can clearly explain the inundation-induced damage behavior for each building material as well as the threshold depth for each damage level.

In addition to this field survey data classification, the effect of coastal topography, geographical features and buildings locations has been treated by means of an analysis of satellite imagery in the plain coast of Ishinomaki city by creating damage map. Previous studies have developed and analyzed integrative remote sensing techniques in assessing building vulnerability to tsunami hazard. High resolution satellite imagery, which has become available in the last few years, makes satellite remote sensing more useful in disaster management since even the damage status of individual buildings can be identified without visiting the sites of disasters [17] [18]. Recent advancements in the field of the management of the databases and the computer information systems made the GIS as an ideal instrument for analyzing satellite maps in the disaster management field by using a multi-scenario approach [19]-[21]. Several topographic factors of elevation, slope, coastal proximity, vegetation, river and water canals are incorporated by the AHP to construct a weighting scheme for the geospatial variables and assessing tsunami vulnerability [22]-[28].

In our case study, the satellite image of Ishinomaki plain coast, which is shown in Figure 1, is analyzed through GIS with appropriate geographical factors to produce the damage map in five classifications. The impact of Kitakami river and water canals floods in the creation of the building vulnerable map is one of the main distinctive aspects of this coastal topography analysis over similar studies.

The experience of historical hazardous events through field surveys together with obtaining information 


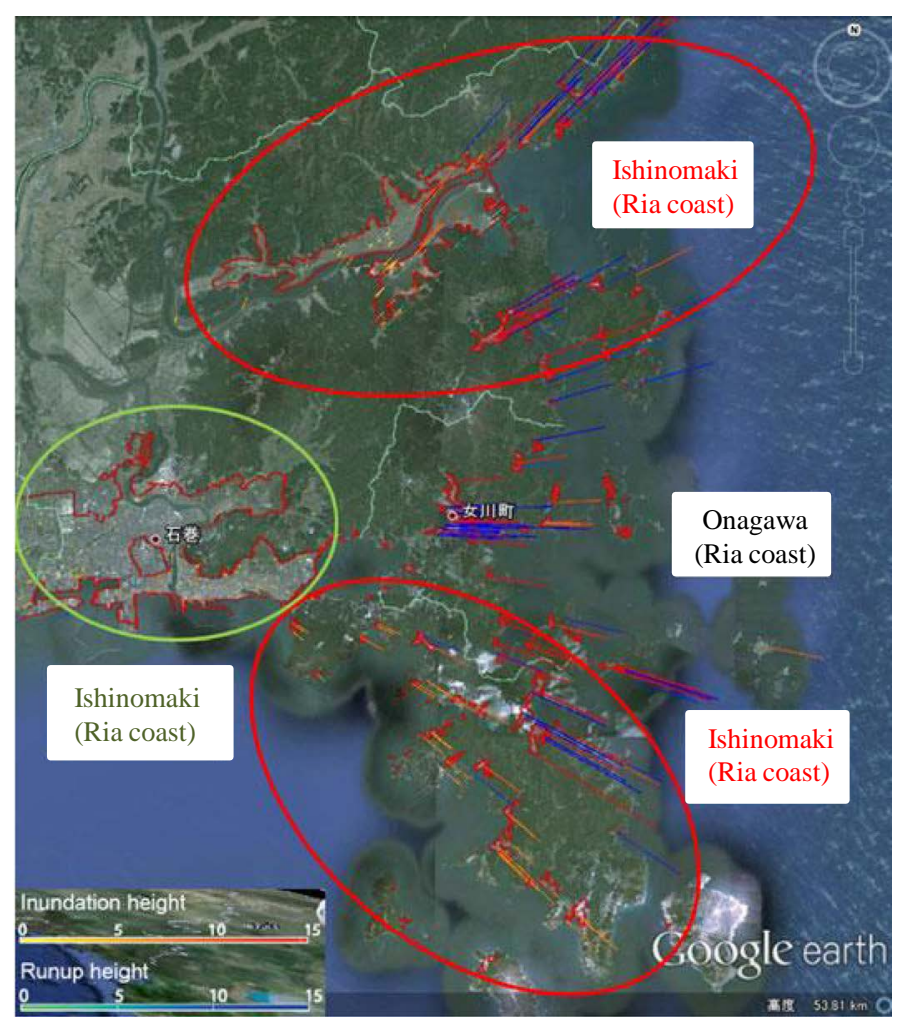

Figure 1. Area map of Ishinomaki city showing the plain coast and ria coast [29].

through GIS, management authorities pre-plans appropriate response activities in order to minimize the damages of a future similar event. These disaster risk managements include activities such as providing better evacuation routes and safe places or shelters, educations for public, construction of tsunami barriers and new regulations for building construction.

\section{Data and Methods}

The first part of this study dedicated to evaluate the building materials behavior and damage because of tsunami inundation according to the field survey conducted by the MLIT provided in database format. In the second part the costal topography impact is treated through damage map produced through GIS incorporated with AHP methodology for the plain coast area. The coastal topography effect on inundation based building damage is investigated by defining shore line, elevation, slope, river and vegetation by means of GIS as a tool to analyze Ishinomaki plain coast satellite image. The analysis results aim to reflect potential differences in damage probabilities related to the tsunami inundation, construction materials and the buildings' location according to the damage map.

\subsection{Building Damage Classification Method}

According to MLIT survey the damage levels were categorized in six classes: 1) Low damage, (some part of building damage and water between ground and first floor), 2) Slightly low damage (half damage and water between ground and first floor), 3) Moderate damage (half damage), 4) High damage (water over than first floor and completely destroyed), 5) Collapse and 6) Washed away. Moreover, the main building characteristics, including building construction material, number of stories and buildings locations were included. An example of such building damage data for affected area in Ishinomaki city is represented in Table 1 for RC.

In this table, building damages are classified based on the measure of tsunami inundation depth. Similar files were available for steel, wood and lightweight building materials named as others in our classifications. 
Table 1. Example of building damage data for whole affected area in Ishinomaki city of Japan.

\begin{tabular}{|c|c|c|c|c|c|c|c|}
\hline & Low & Slightly low & Moderate & High & Collapse & Washed away & Total \\
\hline$\sim 0.5 \mathrm{~m}$ & 46 & 29 & 7 & & & & 82 \\
\hline $0.5 \sim 1.0$ & 39 & 160 & 32 & & 1 & 1 & 233 \\
\hline $1.0 \sim 1.5$ & 8 & 94 & 38 & 4 & 2 & & 146 \\
\hline $1.5 \sim 2.0$ & 1 & 15 & 23 & 10 & 7 & 2 & 58 \\
\hline $2.0 \sim 2.5$ & & 7 & 14 & 29 & 22 & 2 & 74 \\
\hline $2.5 \sim 3.0$ & & 2 & 16 & 19 & 20 & 1 & 58 \\
\hline $3.0 \sim 3.5$ & & & 11 & 28 & 24 & & 63 \\
\hline $3.5 \sim 4.0$ & & & 12 & 15 & 22 & 4 & 53 \\
\hline $4.0 \sim 4.5$ & & & 6 & 13 & 13 & 1 & 33 \\
\hline $4.5 \sim 5.0$ & & & & 10 & 4 & & 14 \\
\hline $5.0 \sim 5.5$ & & & & 11 & 10 & 4 & 25 \\
\hline $5.5 \sim 6.0$ & & & 7 & 12 & 4 & 1 & 24 \\
\hline $6.0 \sim 6.5$ & & & 1 & 1 & 9 & & 11 \\
\hline $6.5 \sim 7.0$ & & & & 1 & 13 & & 14 \\
\hline $7.0 \sim 7.5$ & & & & & 1 & & 1 \\
\hline $7.5 \sim 8.0$ & & & & & & & 0 \\
\hline $8.0 \sim 8.5$ & & & & 2 & 1 & 1 & 4 \\
\hline $8.5 \sim 9.0$ & & & & 1 & 5 & 2 & 8 \\
\hline $9.0 \sim 9.5$ & & & & 2 & 6 & & 8 \\
\hline $9.5 \sim 10.0$ & & & & 1 & 2 & 5 & 8 \\
\hline $10.0 \sim 10.5$ & & & & & 2 & & 2 \\
\hline $10.5 \sim 11.0$ & & & & & 4 & 3 & 7 \\
\hline $11.0 \sim 11.5$ & & & & 1 & & & 1 \\
\hline $11.5 \sim 12.0$ & & & 1 & 2 & 2 & & 5 \\
\hline $12.0 \sim 12.5$ & & & & & & & 0 \\
\hline $12.5 \sim 13.0$ & & & & & & & 0 \\
\hline $13.0 \sim 13.5$ & & & & & 1 & & 1 \\
\hline $13.5 \sim 14.0$ & & & & & & & 0 \\
\hline $14.0 \sim 14.5$ & & & & & & & 0 \\
\hline $14.5 \sim 15.0$ & & & & & & & 0 \\
\hline $15.0 \sim 15.5$ & & & & & & & 0 \\
\hline $15.5 \sim 16.0$ & & & & & & & 0 \\
\hline $16.0 \sim 16.5$ & & & & & & & 0 \\
\hline $16.5 \sim 17.0$ & & & & & & & 0 \\
\hline $17.0 \sim 17.5$ & & & & & & & 0 \\
\hline $17.5 \sim 18.0$ & & & & & & & 0 \\
\hline $18.0 \sim 18.5$ & & & & & & & 0 \\
\hline $18.5 \sim 19.0$ & & & & & & & 0 \\
\hline $19.0 \sim 19.5$ & & & & & & & 0 \\
\hline $19.5 \sim 20.0$ & & & & & & & 0 \\
\hline $20.0 \mathrm{~m} \sim$ & & & & & & & 0 \\
\hline Total & & & & & & & 933 \\
\hline
\end{tabular}


The data were provided for 63,157 buildings where the number of buildings in the inundated area of Ishinomaki city and ones in the plain coast area (look to Figure 1), for four different construction types are listed in Table 2 as well as their percentage distribution as shown in Figure 2.

As illustrated in the Figure 2, nearly 95\% of buildings in Ishinomaki city can be classified either wooden or other fragile material.

Other important buildings characteristic provided by MLIT was number of stories. It has been explained in some previous studies that more number of stories per building the stronger the building construction because of their structural design to support heavier loads. Since based on MLIT database about $98 \%$ of buildings found to be two floors with few multi stories buildings that are located mostly in safe areas, building damage due to the number of stories is neglected in this study.

The MLIT survey analysis method in this study covers an investigation on damage level distribution based on

Table 2. Number of buildings categorized for different building materials.

\begin{tabular}{ccc}
\hline Building Materials & Ishinomaki City & Ishinomaki-Plain Coast \\
\hline Concrete & 933 & 692 \\
Steel & 2450 & 1526 \\
Wooden & 45,976 & 24,997 \\
Others & 13,798 & 6258 \\
Total & $\mathbf{6 3 , 1 5 7}$ & $\mathbf{3 3 , 4 7 3}$ \\
\hline
\end{tabular}
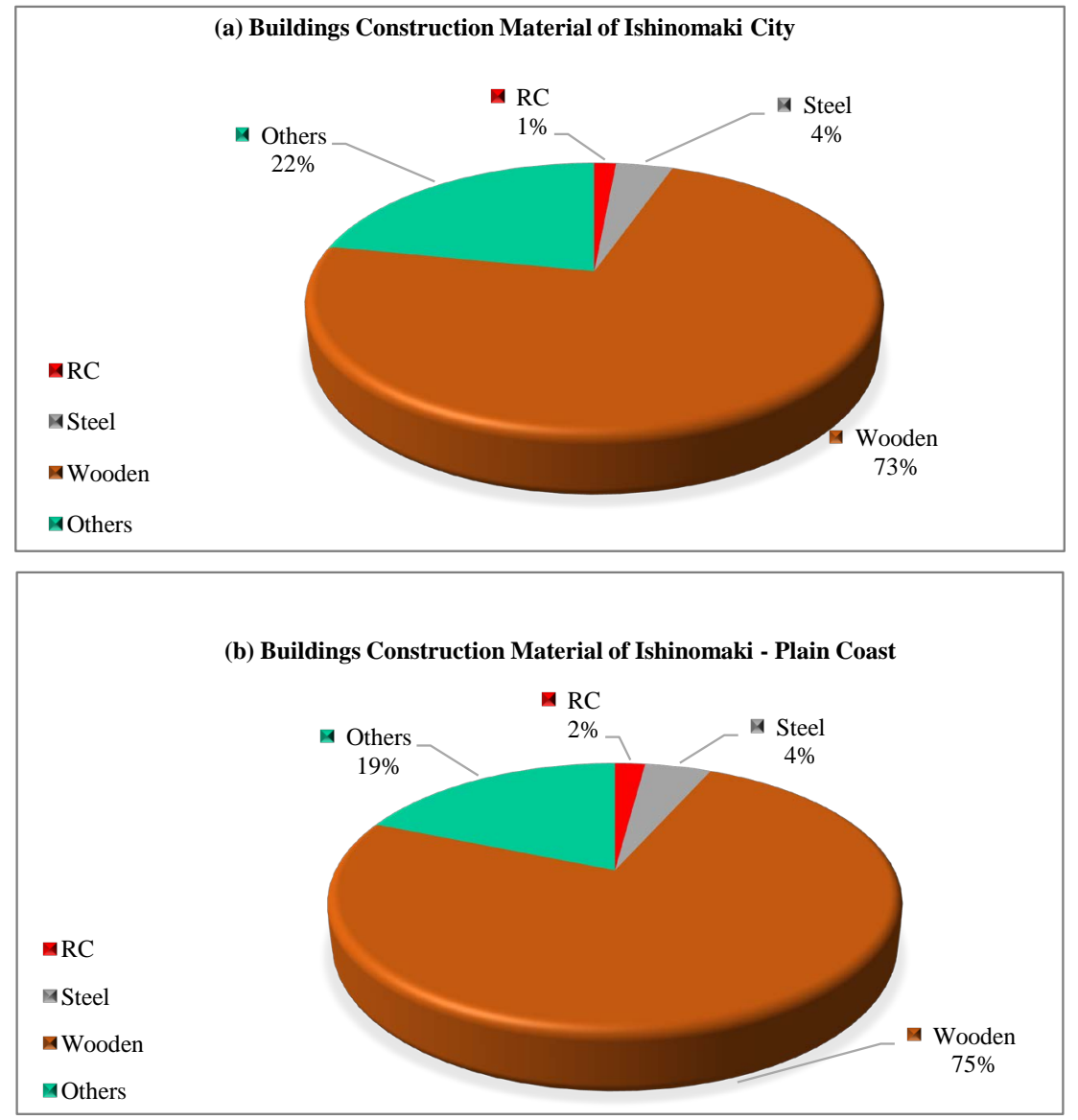

Figure 2. Percentage distribution of different structural building types for (a) Ishinomaki city, (b) Ishinomaki plain coast area in Figure 1. 
inundation depth, building damage distribution with considering both structural material and inundation depth in Ishinomaki city. For necessary occasions, the similar data analysis is applied to buildings located in the plain coastal area for comparison. Several data classifications were performed to extract valuable charts to assess the impact of construction material in amount of damage. Finally, an analysis of the impact of the coastal topography in the amount of building damage for 33,473 buildings of Ishinomaki city plain coast is provided. For this purpose, Arc GIS software tool based on AHP method is used to analyze the satellite image and classify the vulnerable areas.

\subsection{Damage Map}

In this study, remote sensing data captured by GeoEye-1 a Very High Resolution (VHR) optical satellite with a pixel size about $0.41 \mathrm{~m}$ was used to identify critical geographical elements such as buildings, transport infrastructure and the inundation area due to the tsunami event in order to estimate the damage and risk in plain coast area of Ishinomaki City in Miyagi Prefecture as shown in Figure 3.

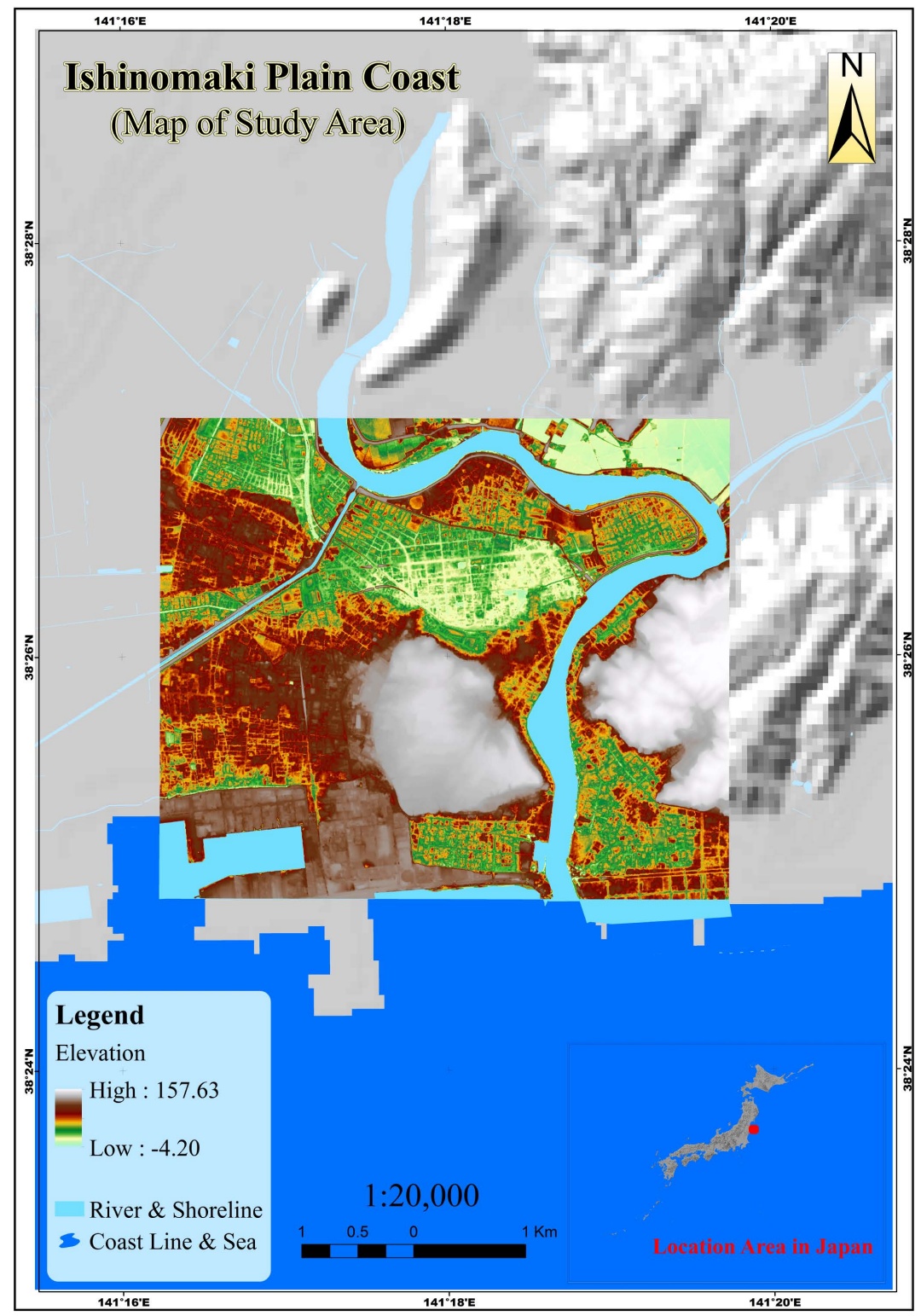

Figure 3. Case study site in Ishinomaki, Japan. 
We extracted the factors of elevation and slope from a Digital Elevation Model (DEM) obtained from the Geospatial Information Authority of Japan while the Normalized Difference Vegetation Index (NDVI) for vegetation density is extracted from Geoeye-1 image and Image Analysis toolbar in ArcGIS 10.2.1 software. The shoreline distance and river distance were measured from the vector maps of the study area.

The damage by tsunami is then estimated by applying AHP to all the mentioned factors. The damage assessment can be displayed via GIS in terms of spatial multi - criteria analysis on a map of the tsunami damage area.

\subsubsection{Elevation}

A digital elevation model was created from elevation data obtained from GSI. DEM was downloaded from http://fgd.gsi.go.jp/download/GsiDLSelFileServlet. The mesh elevation data created by interpolating to the elevation point at center point in 0.2 seconds (about 5 meter) mesh that is from the value of elevation (ground data) measured by airborne laser. The height accuracy of the $5 \mathrm{~m}$ mesh elevation from the airborne laser is less than $0.3 \mathrm{~m}$ and the standard deviation of the altitude acquisition position (from the photogrammetry) is less than 1.0 meter. The data were in JPGIS (format) converted to shapefile in point format using base map viewer converter software version 4.00 (FGDV) provided by GSI.

Finally, this point format was converted to raster for creating the digital elevation model via Arc GIS 10.2.1 software and raster interpolation toolset function.

\subsubsection{Slope}

The slope was determined as the rate of maximum change in $\mathrm{z}$ value from each cell of the satellite image. The use of a $\mathrm{z}$-factor is essential for correct slope calculations when the surface $\mathrm{z}$ units are expressed in units different from the ground $x, y$ units. The range of values in the output depends on the type of measurement units. The range of slope values is 0 to 90 for degrees and 0 to essentially infinity for percent rise. We created a slope map using the surface creation and analysis tools of the ArcGIS 10.2.1 software to use a third-order finite-difference method for calculating the slope [30] [31].

\subsubsection{Distance from Shoreline}

The distance from the shoreline was created in a polyline file for buffering the distance from the shoreline to the land. We computed the distance using the proximity and the Euclidean distance analyst tool in the ArcGIS 10.2.1 software. The distance is based on the historical report of the maximum run-up in the area of study. We used the "Equation (1)" to classify coastal proximity and shoreline distance buffering from Bretschneider and Wybro (1976) [32]:

$$
\log X_{\text {max }}=\log 1400+\frac{4}{3} \log \left(\frac{Y 0}{10}\right)
$$

where $X_{\max }$ is the maximum reach of the tsunami over land, and $Y 0$ is the tsunami height at the shore line.

We classified distance buffers in five classes based on the "Equation (1)" in order to create a tsunami damage map. It explains that $4.55 \mathrm{~m}$ to $7.09 \mathrm{~m}$ of run-up can reach a distance of $489.94 \mathrm{~m}$ from the shoreline, $7.09 \mathrm{~m}$ to $9.64 \mathrm{~m}$ of run-up can reach $885.76 \mathrm{~m}, 9.64 \mathrm{~m}$ to $12.18 \mathrm{~m}$ of run-up can reach $1332.84,12.18 \mathrm{~m}$ to $14.73 \mathrm{~m}$ of run-up can reach $1821.46 \mathrm{~m}$ and $14.73 \mathrm{~m}$ to $17.27 \mathrm{~m}$ of run-up can reach more than $2345.53 \mathrm{~m}$.

\subsubsection{Distance from (Kitakami) River and Water Canal}

The Kitakami River, the fourth largest river in Japan and the downstream branches into two water canal, OldKitakami river and Kitakami river. Old-Kitakami river flows on a fertile plain which has been highly developed for agriculture and industries and this water canal passes through the study area, while Kitakami river flows through a narrow valley into a small bay faced to the Pacific Ocean. It can be seen that the tsunami had reached 8 to $10 \mathrm{~km}$ or more off the coastline towards inland around Kitakami river and Old Kitakami river and the elevation in this region was extremely low, ranging between 0 and $2 \mathrm{~m}$ [33]-[35].

Kitakami-unga and Kitakami canals are artificial canals with an average elevation of $-9 \mathrm{~m}$ below sea level along $15.8 \mathrm{~km}$. Kitakami canal that ran across the city and then inundated the inland area [36]. Similarly to the river study, based on the historical report of the inundation area and inundation depth maps, we evaluated the inundated area along the water canal.

The elevation, river distance and shoreline distance were classified into five classes of damage using the Jenks 
natural breaks method. This classification method indicates by picking the class breaks in best group similar values, maximize the differences between classes and minimize value differences between data within the same class and emphasize the differences between the reclassified classes.

\subsubsection{NDVI and Vegetation}

The NDVI is a common tool for identifying and characterizing vegetation and a measure of the difference in reflectance between these wavelength ranges that take values between -1 and 1 , while vegetated areas produce values starting around 0.4 and approaching 1.0 and values $<0$ indicating no vegetation [37] [38].

"Equation (2)" was used for NDVI calculation and specification:

$$
\mathrm{NDVI}=\frac{(\mathrm{NIR}-\mathrm{RED})}{(\mathrm{NIR}+\mathrm{RED})}
$$

In which for GeoEye-1 Band 4 is NIR (near infrared band) and Band 3 is red.

We classified elevation and the distance for river, canal and shoreline based on the values described in Table 3 .

\subsubsection{GIS and AHP for Damage Mapping}

Cell-based modeling in spatial analysis was used to specify the damage area due to tsunami hazard. Cells are classified into five classes of damage in the numbers of 1, 2, 3, 4 and 5, which represent low, slightly low, medium, slightly high, and high damage classes for different inundation depth.

AHP is a Multi-Criteria Decision-making Analysis (MCDA) approach introduced by Saaty $(1977,1980)$. It relies on the series of pair-wise comparisons between each factor relative to other factors to make a scaled set of preferences in ranges from 1 to 9 to score the importance of each factor (Saaty, 2008). Table 4 describes the fundamental scale of absolute numbers which is named the Saaty nine-point comparison scale. As we mentioned each number explains the relative importance of each factor [22] and [39].

All of tsunami damage factors are overlaid and weighted based on their dominant influences in determining the class of tsunami induced damage. The relative importance of each factor within the hierarchy is determined

Table 3. Tsunami damage classes based on elevation, slope, shoreline distance, river distance and vegetation.

\begin{tabular}{|c|c|c|c|c|c|c|c|}
\hline \multirow{3}{*}{ Damage class } & \multicolumn{7}{|c|}{ Factors name } \\
\hline & \multirow{2}{*}{ Elevation (m) } & \multirow{2}{*}{ Slope (\%) } & \multirow{2}{*}{$\begin{array}{c}\text { Shoreline } \\
\text { distance (m) }\end{array}$} & \multicolumn{2}{|c|}{ River distance (m) } & \multicolumn{2}{|c|}{ Vegetation } \\
\hline & & & & Kitakami & Unga canal & Index & Density \\
\hline High (5) & $-4--1$ & $0-1$ & 0 - 489.94 & - & - & $-0.998-0.151$ & Low \\
\hline Slightly high (4) & $-1-0$ & $1-3$ & $489.94-885.76$ & - & - & $0.151-0.164$ & Slightly low \\
\hline Medium (3) & $0-2$ & $3-6$ & 885.76 - 1332.84 & $0-160$ & - & $0.164-0.188$ & Medium \\
\hline Slightly low (2) & $2-8$ & $6-8$ & $1332.84-1821.46$ & $160-680$ & $0-300$ & $0.188-0.218$ & Slightly high \\
\hline Low (1) & $>8$ & $>8$ & $1821.46-2345.53$ & $>680$ & $>300$ & $0.218-0.556$ & High \\
\hline
\end{tabular}

Table 4. The Saaty nine-point comparison scale [39].

\begin{tabular}{cll}
\hline Score & Definition & Explanation \\
\hline 1 & Equal importance & Two factors contribute equally to the objective. \\
5 & Weak importance of one over another & $\begin{array}{l}\text { The judgment is slightly favor one factor over another. } \\
\text { The judgment is strongly favor one factor over another. }\end{array}$ \\
7 & Demonstrated importance & $\begin{array}{l}\text { A factor is strongly favored and its dominance is demonstrated } \\
\text { in practice. }\end{array}$ \\
9 & Absolute importance & $\begin{array}{l}\text { The evidence favoring one factor over another is of the highest } \\
\text { possible order of affirmation. }\end{array}$ \\
$2,4,6,8$ & $\begin{array}{l}\text { Intermediate values between the two } \\
\text { adjacent judgments }\end{array}$ & When compromise is needed. \\
\hline
\end{tabular}


by their weights (Saaty, 1977 \& 1980) with a pairwise comparison as shown in Table 5 . The hierarchical interactions based on the respective importance of each factor were computed by estimating the numerical score. When there are evaluation criteria/objectives, decision makers must carry out a pairwise comparison. The scores are made by the subjective definition of the investigator in determining the importance of each factor [24]-[26].

The first eigenvector is computed based on the pairwise comparison matrix shown in Table 5. an approximation of eigen vector and eigen value of a reciprocal matrix can be obtained by through the following method: 1) sum of each column of the reciprocal matrix 2) Then we divided each element of the matrix with the sum of its column, we have normalized relative weight where the sum of each column is 1 as shown in Figure 4. The normalized principal eigen vector can be obtained by averaging across the rows. The obtained normalized principal eigenvector explains that shoreline distance has the highest weight (42.16\%), followed by elevation (14.92\%), slope (8.57\%), river distance (26.60\%) and vegetation density (7.74\%) as shown in Figure 4.

AHP is subjective and tolerates inconsistency through the amount of redundancy by providing a measure of inconsistency assessment, which is shown by Consistency Ratio (CR). If the value of CR is smaller or equal to $10 \%$, the inconsistency is acceptable. CR indicates the probability that the matrix judgments were randomly generated and it is defined as the ratio of the Consistency Index (CI), which is the degree of logical consistency among pair-wise comparisons, to the Random consistency Index (RI) which is the average CI value of randomlygenerated comparison matrices [40].

"Equations (3)" and "Equation (4)" describe the algorithms for CR and CI calculation:

$$
\begin{aligned}
& \mathrm{CR}=\frac{\mathrm{CI}}{\mathrm{RI}} \\
& \mathrm{CI}=\frac{\lambda_{\text {max }}-n}{n-1}
\end{aligned}
$$

In which:

$\lambda_{\max }$ is the maximum eigenvalue of the judgement matrix and calculated from the sum of all factors and is multiplied by its eigen vector which is $42.16 \%$.

$n$ is the size of the comparison matrix. In this study, $n=5$.

The RI is based on the random consistency index as shown in Table 6 was used 1.11 for five factors of normalized matrix in Figure 4.

So the consistency index, CI, is calculated 0.093 and CR is $8.37 \%$.

We calculated each raster cell-by-cell basis of the factor to its weight using any GIS system with overlay ca-

\begin{tabular}{|c|c|c|c|c|c|}
\hline \multirow{2}{*}{$\begin{array}{c}\text { Pairwise } \\
\text { comparison }\end{array}$} & \multicolumn{5}{|c|}{ Factors name } \\
\hline & Elevation & Slope & Shoreline distance & River distance & Vegetation \\
\hline Elevation & 1.00 & 2.00 & 0.33 & 0.50 & 2.00 \\
\hline Slope & 0.50 & 1.00 & 0.25 & 0.33 & 1.00 \\
\hline Shoreline distance & 3.00 & 4.00 & 1.00 & 2.00 & 5.00 \\
\hline River distance & 2.00 & 3.00 & 0.50 & 1.00 & 4.00 \\
\hline Vegetation & 0.50 & 1.00 & 0.20 & 0.25 & 1.00 \\
\hline
\end{tabular}

Table 5. Pair-wise comparison of factors

\begin{tabular}{|c} 
Eevation \\
Slope \\
Shoreline distance \\
River distance \\
Vegetation
\end{tabular}$\quad\left[\begin{array}{lllll|}0.1429 & 0.1818 & 0.1460 & 0.1224 & 0.1538 \\
0.0714 & 0.0909 & 0.1095 & 0.0816 & 0.0769 \\
0.4286 & 0.3636 & 0.4380 & 0.4898 & 0.3846 \\
0.2857 & 0.2727 & 0.2190 & 0.2449 & 0.3077 \\
0.0714 & 0.0909 & 0.0876 & 0.0612 & 0.0769\end{array}\right]$

Figure 4. Normalized matrix. 
Table 6. Value of the Random Index (RI) [38].

\begin{tabular}{|c|c|c|c|c|c|c|c|c|c|c|}
\hline \multirow{2}{*}{$\begin{array}{l}\text { Random Consistency } \\
\text { Index }\end{array}$} & \multicolumn{10}{|c|}{ Matrix Size } \\
\hline & 1 & 2 & 3 & 4 & 5 & 6 & 7 & 8 & 9 & 10 \\
\hline RI & 0.00 & 0.00 & 0.52 & 0.89 & 1.11 & 1.25 & 1.35 & 1.40 & 1.45 & 1.49 \\
\hline
\end{tabular}

pabilities. A Weighted Linear Combination (WLC) analysis is very straightforward in a raster GIS, and each factors are combined by applying a weight, to each followed by a summation of the results to proceed a suitability map. "Equations (5)" describes the suitability calculation [22] and [36]-[40].

$$
S=\sum W_{i} \cdot X_{i}
$$

where:

$S=$ Suitability

$W_{i}=$ Weight of factor.

$X_{i}=$ the criterion score of factor $i$.

We estimated raster calculator in map algebra menu using the spatial analyst tools of ArcGIS 10.2.1 to produce damaged map by applying "Equations (5)".

\section{Results and Discussion}

The first part is representing results of building damage for different construction materials. Second part shows the result of GIS for building damage map.

\subsection{Building Damage Characteristics}

In this section, based on surveyed data several statistical analysis results of building damage for different construction materials are provided and discussed. The damage level percentage distribution of different building materials are plotted for different inundation depth ranges in several sets of figures: 1) Tsunami inundation depth only 2) Construction material only, 3) Construction material and inundation depths together.

\subsubsection{Tsunami Inundation Depth}

The tsunami inundation depth for buildings located in Ishinomaki city was obtained from the MLIT surveyed data and also Geoeye-1 satellite image. According to this data, we classified and summarized the distribution of damage levels based on tsunami inundation depth on an interval of $0.5 \mathrm{~m}$ for the whole city, regardless of building material type. The result is graphically represented in Figure 5.

According to Figure 5, for higher inundation depth the amount of damages is increased. For instance, for an inundation depth interval below $0.5 \mathrm{~m}$ low damage and slightly low damages are the most dominant. The inundation depth in the range of $0.5-1.5 \mathrm{~m}$ about half of the buildings are slightly low damaged while the rest building damages are mostly distributed between low damage and moderate damages. The range between 1.5 $4.0 \mathrm{~m}$ most buildings are collapsed and for inundation depths over $4 \mathrm{~m}$ most of the buildings are washed away. Since for inundation depth over $8 \mathrm{~m}$ over $90 \%$ of buildings are washed away as shown in Figure 5.

\subsubsection{Construction Material}

The wave forces brought by a tsunami cause great damages to fragile buildings. Standing buildings in the path of the waves tend to block the water, and thus the pressure on them increases. The water force can be calculated by using the wave pressure distribution by Tanimoto formula. For example, water just $2 \mathrm{~m}$ deep will impose pressure of approximately $20 \mathrm{KN}$ per square meter, much more than any normal construction can remain undamaged. The deeper the water is, the greater the pressure is [41]. Thus, one of the key factors to minimizing damage caused by tsunamis is to build constructions with basic requirements that can withstand the damage of such storms. When comparing building materials, it was found that RC constructions were more likely to survive the wave forces brought by a tsunami, as compared to masonry and wood constructions, which did not survive well [8]-[16].

This part is dedicated to comparing statistically different building material damage during the east Japan great 

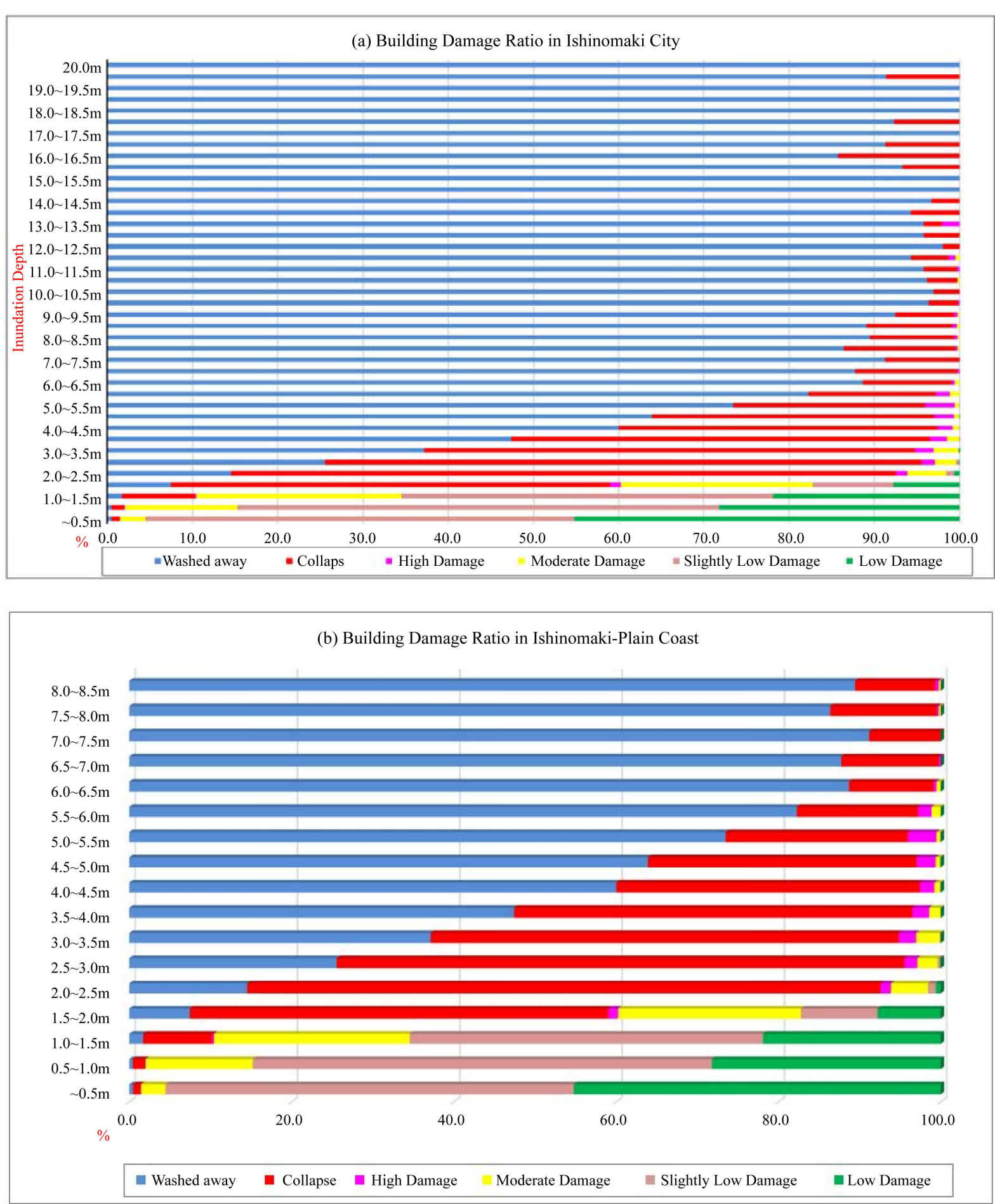

Figure 5. Distribution of the total 52,904 building data surveyed by MLIT (a) Ishinomaki city inundation depth (0 - 20 m); (b) Ishinomaki-plain coast inundation depth $(0-8.5 \mathrm{~m})$.

tsunami 2011 for Ishinomaki city with 63,157 buildings for the whole city and with 33,473 buildings for Ishinomaki plain coast as a case study. Each damaged building was measured and classified according to its damage level (six levels were defined by MLIT), construction material (RC, steel, wooden and other light weight construction such as clay or brick mentioned in text as others). 
The damage data are classified according to the building material as shown in Figure 6 and Figure 7. As it is expected, RC buildings could withstand best against tsunami waves with showing the lowest amount of damage and no RC building is recorded to be washed away. On the other hand, half of the wooden and other fragile structures are either washed away or collapsed. In case of steel, over half of the buildings are either collapsed or highly damaged.

The same extracted date is plotted as a percentage distribution of different building materials and shown in
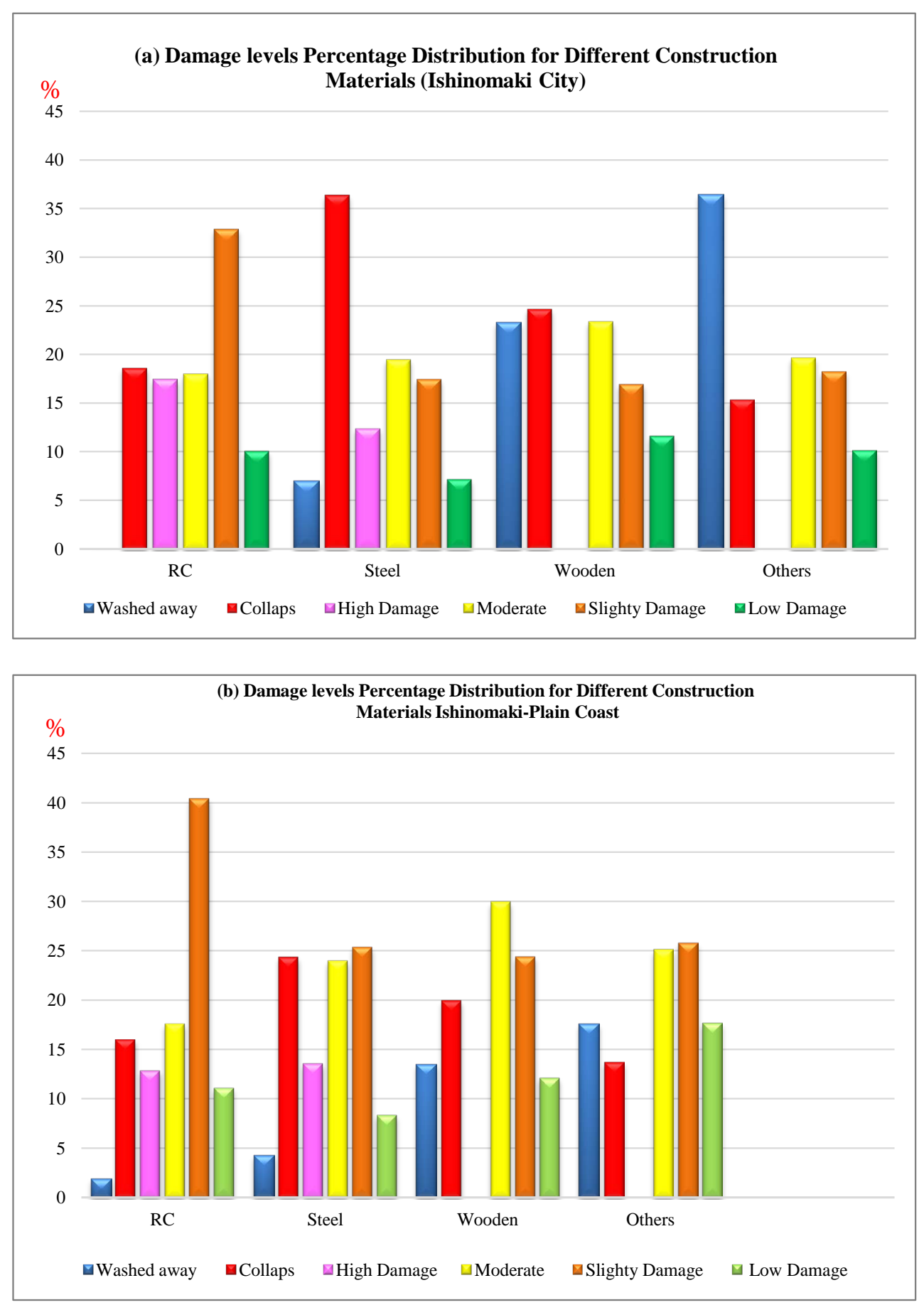

Figure 6. Comparison of damage levels (a) Ishinomaki city (b) Ishinomaki-plain coast for different construction materials RC, steel, wood and others. 

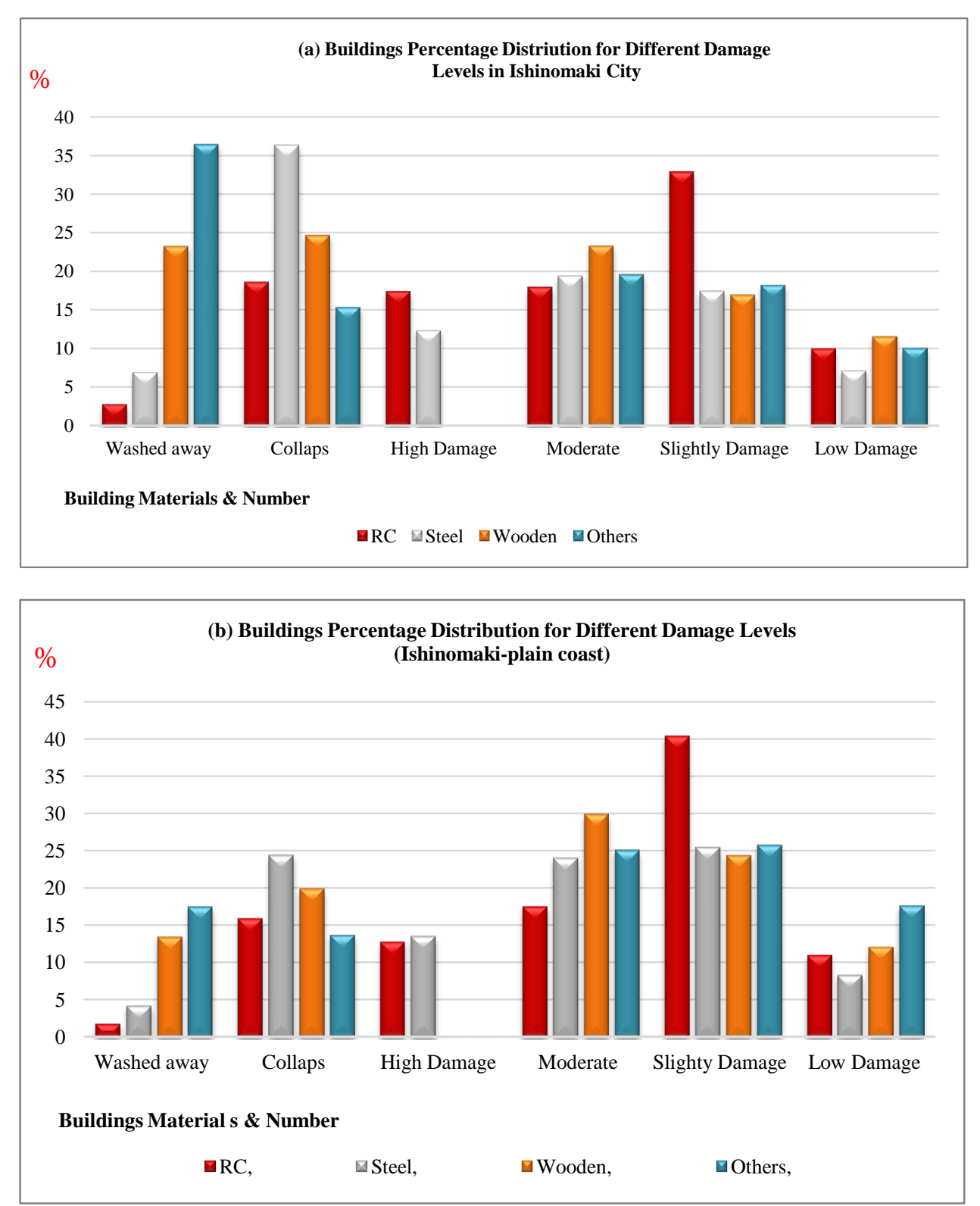

Figure 7. Comparison of damage levels with different building material consideration. (a) Ishinomaki city, (b) Ishinomaki-plain coast.

Figure 7 for the whole city via plain coast area only. By considering collapsing and washed away buildings. Figure 7 via slightly low damage ones, it can be recognized that the plain coast was less affected than whole city. The absence of wooden and others material in high damage levels is another result from this figure. Moreover, by looking to the slightly low damage buildings distribution, it can be concluded that with the same probability, wooden, steel and others material buildings are distributed.

\subsubsection{Combined Effect of Construction Material and Inundation Depth}

As it is mentioned earlier, the deeper the water, the greater the pressure and the greater the amount of damage is expected. By considering the inundation depth on an interval of $0.5-8.5 \mathrm{~m}$, the damage data for the whole Ishinomaki city is classified according to the type of building materials. For a given inundation depth interval, the percentage contribution of each damage level is calculated. The graphical results are shown graphically in Figure 8 for different constructions. According to Figure 8(a), the percentage damage distribution of RC material 

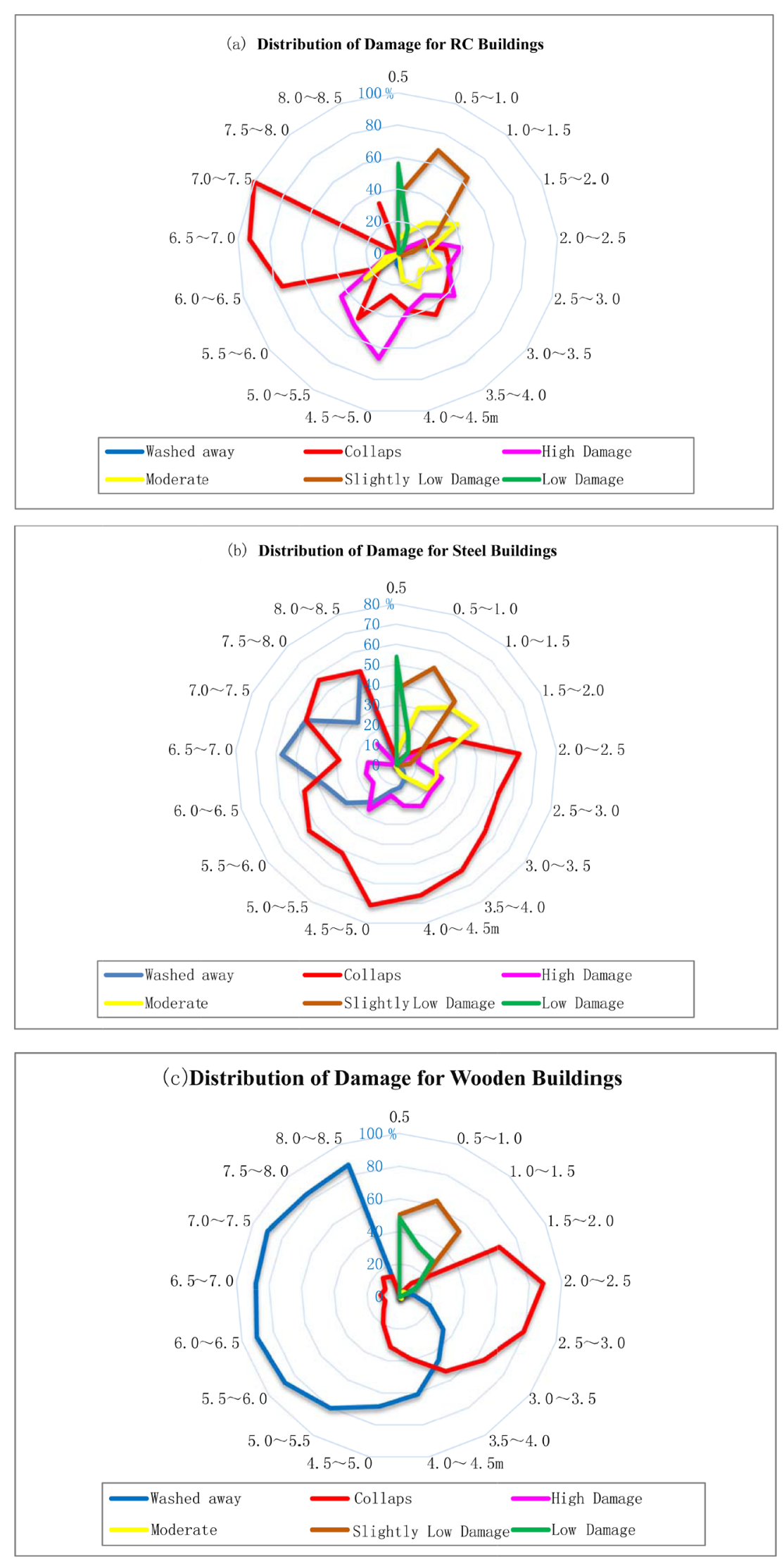


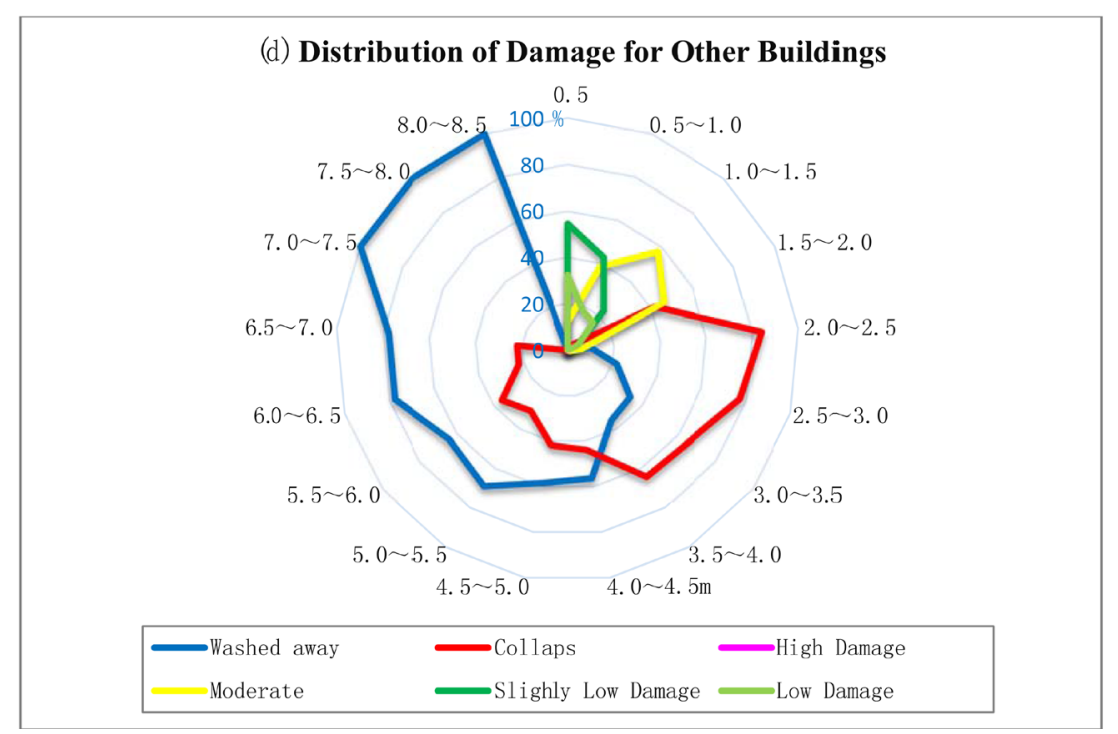

Figure 8. Comparison of tsunami damage for different building material in Ishinomaki city separated for building material as (a) RC, (b) steel, (c) wood and (d) others.

in the inundation depth range less than $2 \mathrm{~m}$ only low and slightly low damages are expected. For the inundation depth of 2.5 - $6.0 \mathrm{~m}$ RC buildings are mostly high damaged since buildings located in inundation depth over 6.0 $\mathrm{m}$ are all collapsed. For steel buildings as depicted in Figure 8(b), for inundation depth less than $2.0 \mathrm{~m}$ low, slightly low and moderate damages are observed. For inundation depth range of 2.0 - $6.5 \mathrm{~m}$ most of steel buildings are collapsed (over 40\%) and for over $6.5 \mathrm{~m}$ is distributed between collapsed and washed away.

Wooden buildings shown in Figure 8(c) and other lightweight structures shown in Figure 8(d) are expressing almost similar damage distributions. In both cases, inundation depth less than $1.5 \mathrm{~m}$ causes low, slightly low, moderate (observed only for others) damages. Woods and other fragile building materials in an inundation depth range of 1.5 - $4.0 \mathrm{~m}$ are mostly collapsed and the inundation depth of $4.0 \mathrm{~m}$ is the threshold for washed away buildings.

With considering inundation depth, the same data used for Figure 8 are classified according to the levels of damage to better the illustration of each structural material contribution in the amount of the damage in each level. The results are shown in Figure 9. These classifications are also valuable because the comparison between different materials becomes possible. According to the Figure 9(a), the washed away level graph shows the threshold inundation depth of $3.0 \mathrm{~m}$ for wooden and other fragile building materials, $4.0 \mathrm{~m}$ for steel building while RC buildings are rarely influenced.

It is also comprehending that for the Figure 9(a), and for the threshold depth of $4 \mathrm{~m}$ over half of wooden or other fragile buildings are washed with similar graphical behavior. Also the collapse figure shown in Figure 9(b) suggests the threshold depth of $1.5 \mathrm{~m}$ to see this phenomenon regardless of building material. Also, it can be observed that wooden and other fragile buildings are collapsed in much less inundation depth compared to RC buildings. According to Figure 9(c), only RC and steel are vulnerable to high damage. According to Figure 9(d), moderate damage for all building materials are distributed in the inundation depth range of $1.0-2.0 \mathrm{~m}$. Slightly low damage buildings are observed mostly in the inundation depth range of $0.5-1.0 \mathrm{~m}$ for all building materials as shown graphically in Figure 9(e). And finally, low damaged buildings are accumulated in inundation depth less than $0.5 \mathrm{~m}$.

\subsection{Tsunami Damage Map}

Figure 10 shows the tsunami damage map in Ishinomaki plain coast area as output of this calculation. We estimated the statistics of the damage map based on the damage classification of five factors used in this study. The result is shown in Table 7 while the damage index of 125,548.39 grid cells ranged between 1 to 5 . The GIS produced tsunami damage map is shown in Figure 10 which is in good agreement with the historical data re- 
(a)Distribution of Damage for Washed away Buildings

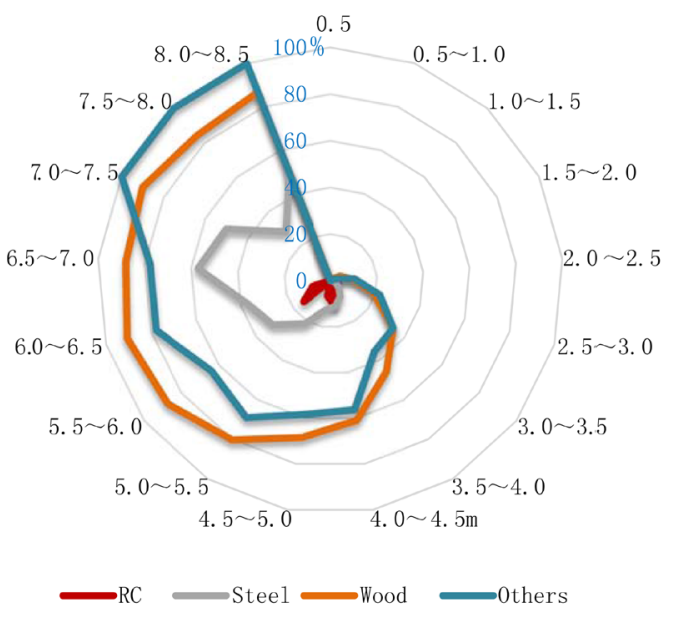

(b) Distribution of Damage for Collaps Buildings

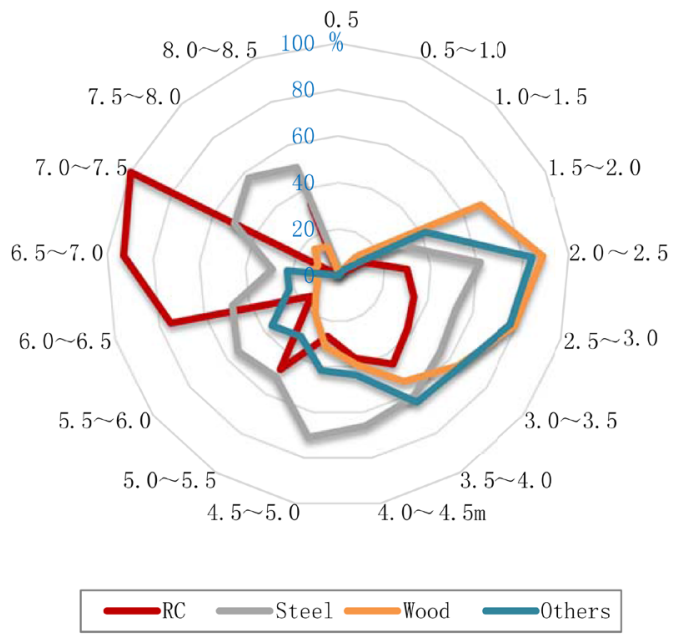

(c)Distribution of Buildings for High Damage Classification

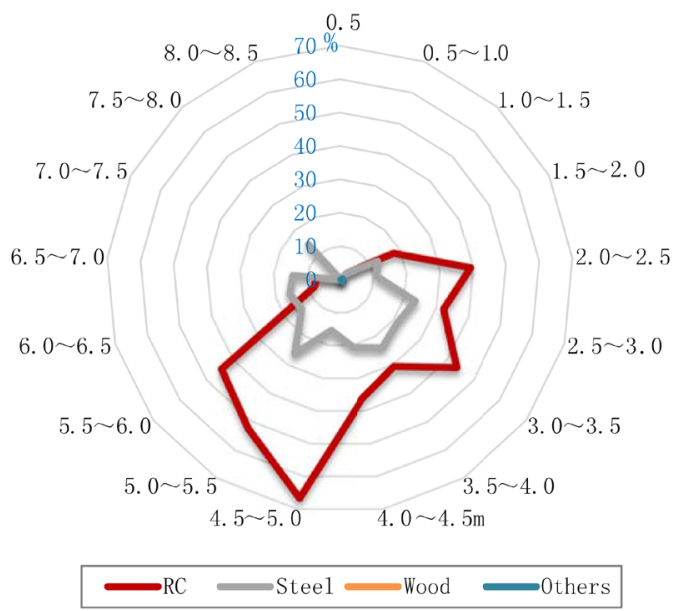



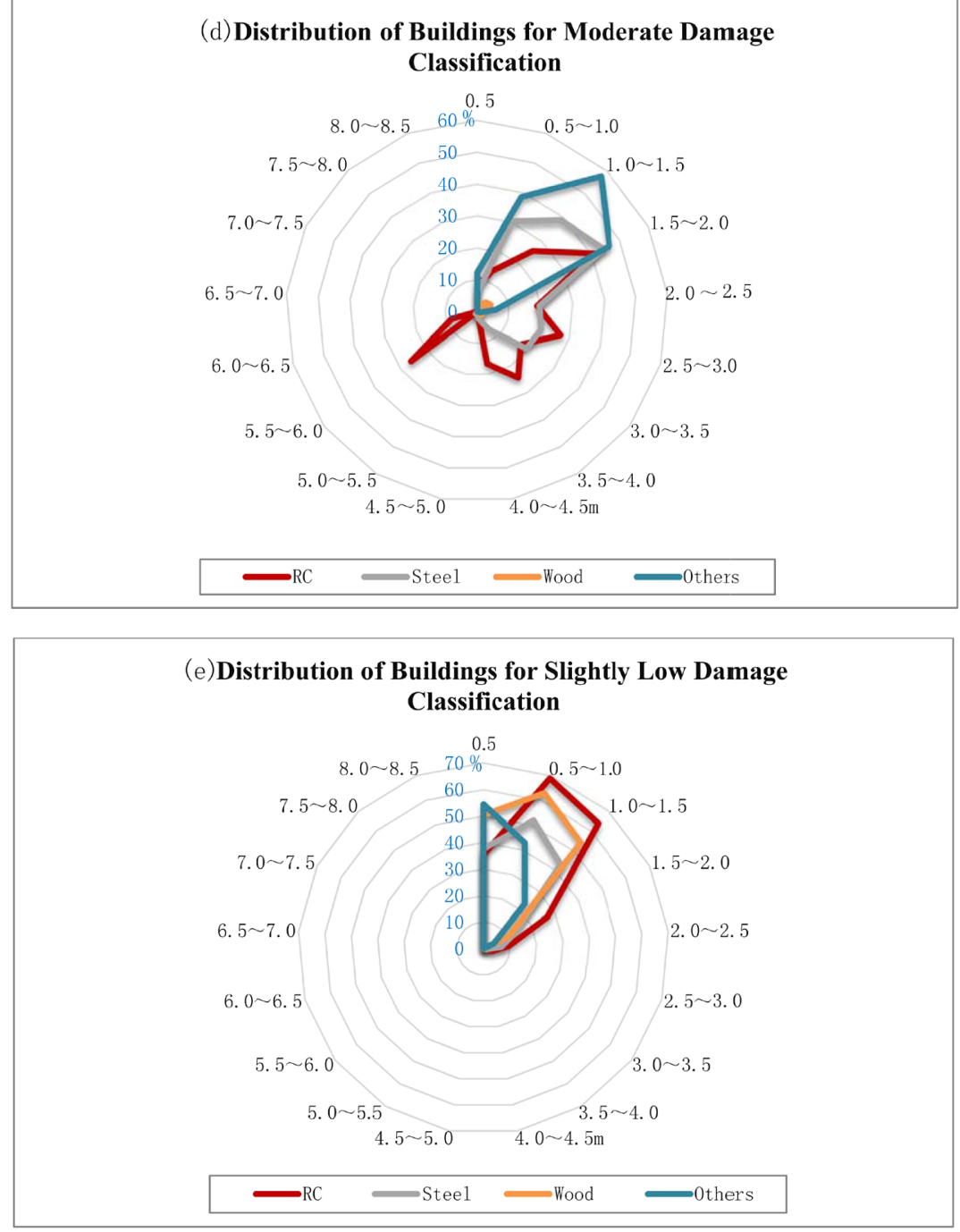

(f) Distribution of Buildings for Low Damage Classification

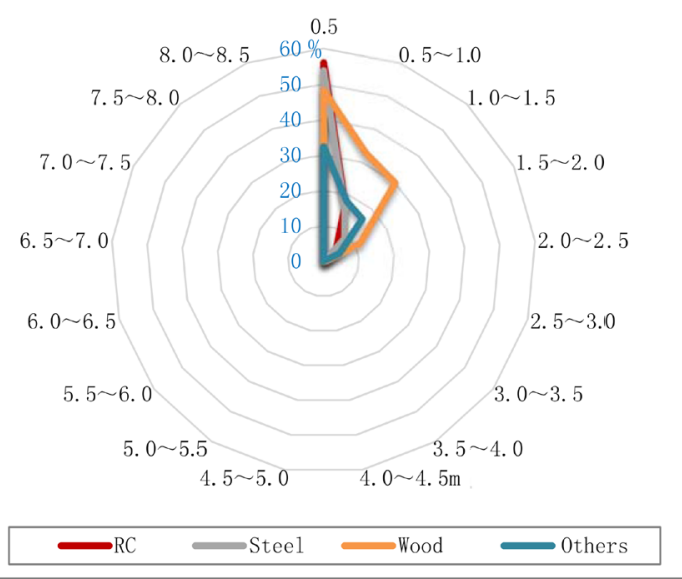

Figure 9. Comparison of tsunami damage for different building material in Ishinomaki plain coast separated for six different damage levels. (a) Washed away, (b) collapsed, (c) high damage, (d) moderate damage, (e) slightly low damage, (f) low damage. 


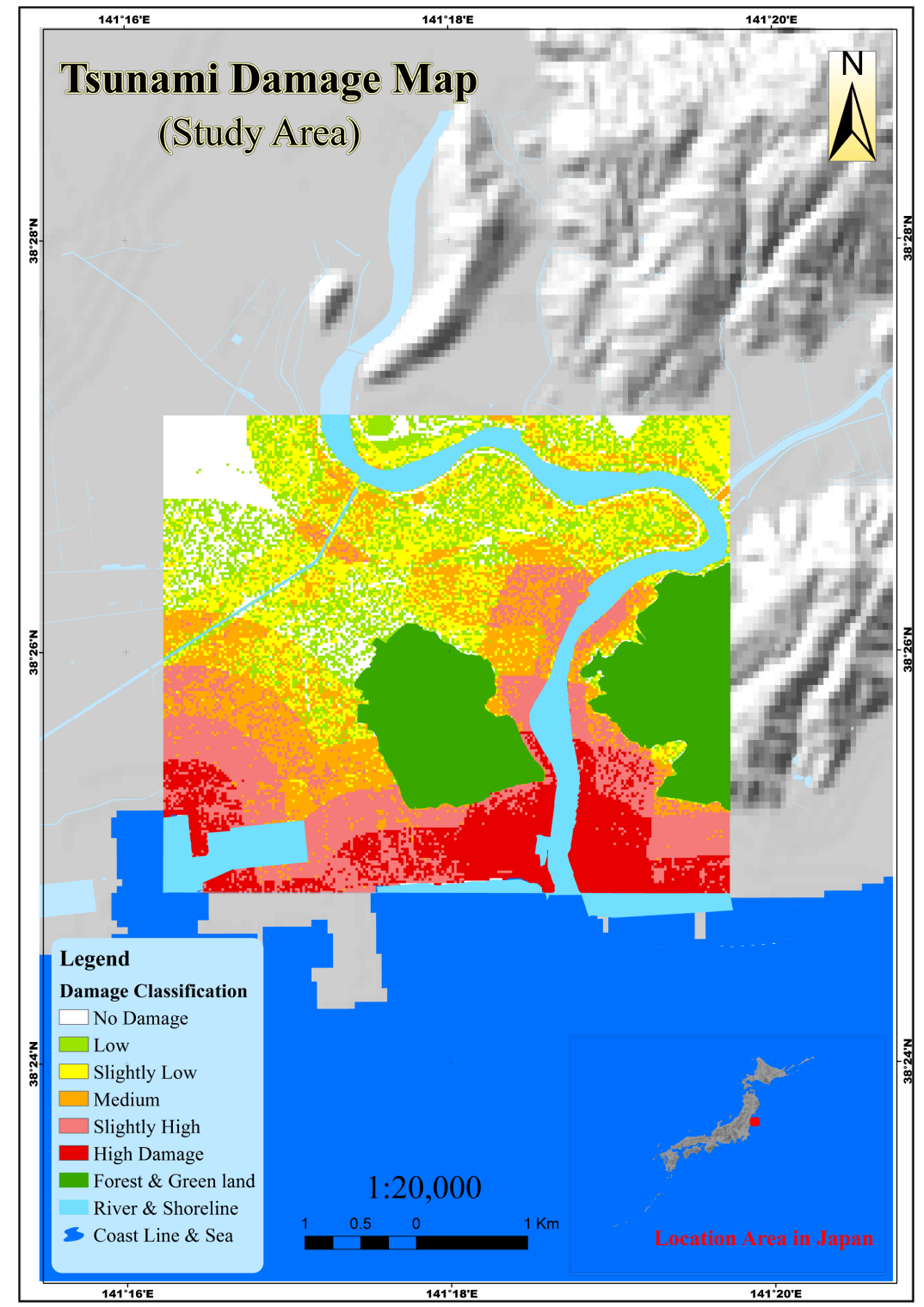

Figure 10. Tsunami damage map of ishinomaki plain coast (study area).

Table 7. Damage area classification and tsunami inundated area.

\begin{tabular}{ccccc}
\hline \multirow{2}{*}{$\begin{array}{c}\text { Damage } \\
\text { Index }\end{array}$} & \multicolumn{4}{c}{ Damage Area Classification } \\
\cline { 2 - 5 } & $\begin{array}{c}\text { Damage } \\
\text { Classification }\end{array}$ & $\begin{array}{c}\text { Damage Value in } \\
\text { Tsunami Damage Map }\end{array}$ & Area $\left(\mathrm{km}^{2}\right)$ & Area (\%) \\
\hline 1 & Low & $1.30-1.59$ & 2.20 & 18.69 \\
2 & Slightly Low & $1.59-1.87$ & 3.08 & 22.76 \\
3 & Medium & $1.87-2.34$ & 3.02 & 21.35 \\
4 & Slightly High & $2.34-2.97$ & 3.22 & 21.71 \\
5 & High & $2.97-4.32$ & 2.65 & 15.48 \\
\hline
\end{tabular}

corded by “GSI” and “2011 Earthquake Tsunami Joint Survey Group” shown in Figure 11. Based on the comparison most of the inundation areas are located in high and slightly high damage areas. 


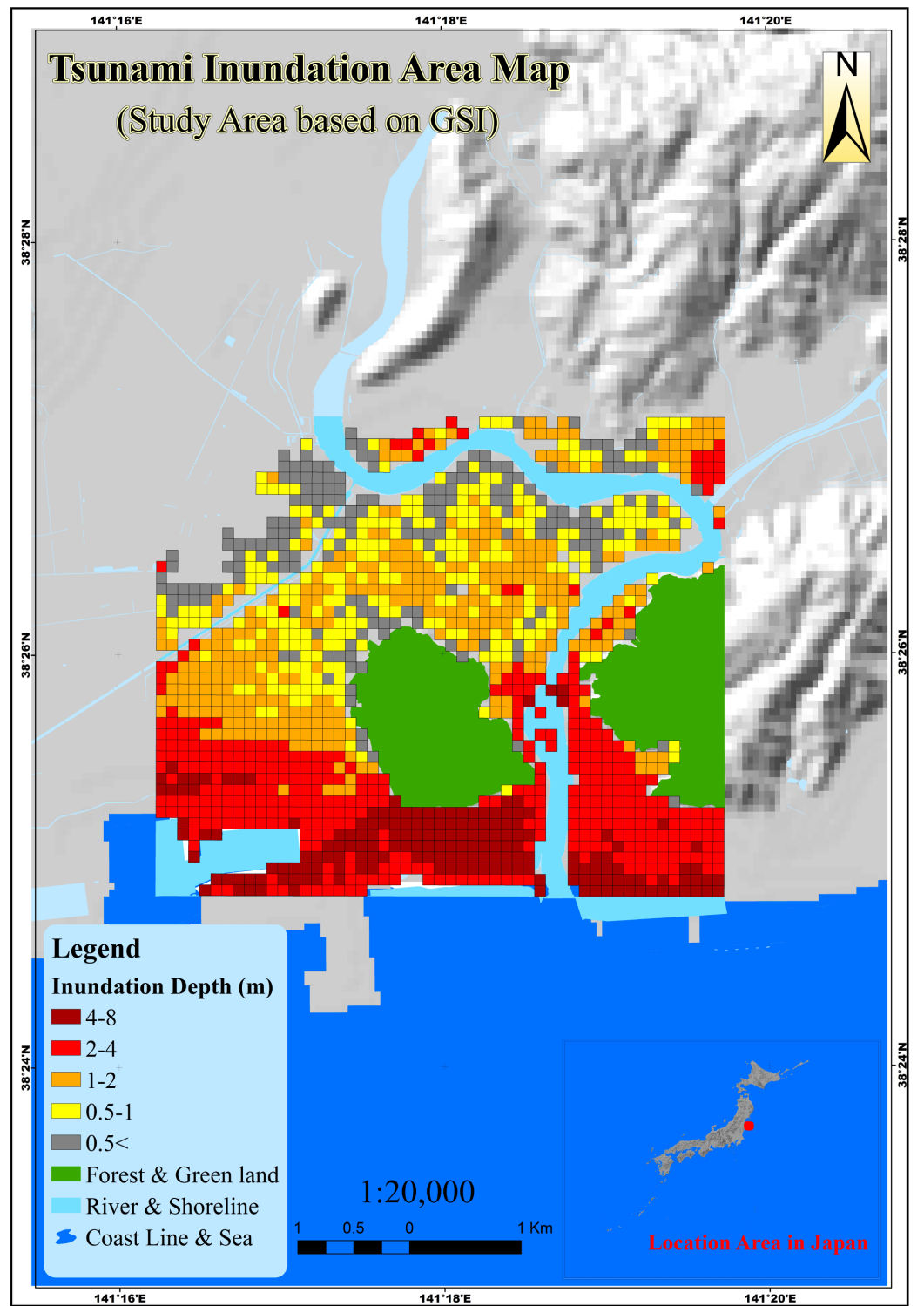

Figure 11. Tsunami inundation map in Ishinomaki-plain coast (published by GSI) [27].

Based on the result of our study, which is shown in Figure 10 the inundation area was estimated $14.16 \mathrm{~km}^{2}$, while GSI reported that the inundation area in Ishinomaki plain coast was $13.46 \mathrm{~km}^{2}$ during the 2011 Japan tsunami.

\section{Conclusions}

Building damage data of Ishinomaki city, with special attention to the plain coast affected area, were classified and analyzed using data surveyed by the MLIT for more than 52,000 structures. The classification includes information on six levels of damage, four types of building materials and damage percentage due to tsunami inundation for each building material which are necessary information for an effective hazard mitigation.

The main findings of this study and their applicability are summarized as below:

- Building damage data of Ishinomaki city, with special attention to the plain coast affected area, were classified and analyzed.

- Damage level percentage distribution for different building materials and buildings percentage distribution for different damage levels for Ishinomaki city and its plain coast were illustrated. 
- For each building material, damage level percentage distribution of different building materials was plotted under inundation depth range of $0-8.5 \mathrm{~m}$. These graphs show the material behavior due to tsunami inundation to assess the damages which are comparable to fragility curves. For each damage level, different inundation threshold depths were also mentioned.

- RC, steel, wooden and other fragile building materials behavior during a tsunami event was compared under different inundation depth. The results show a better resistant performance of RC and steel buildings over wood or other buildings.

- Calculation of damage map and its comparison with a damage map based on surveys, allow us to understand the importance of each geographical factor that has significant influence on damage. By means of GIS tool, the damage areas are followed by building material behavior schematics. One can assess the amount of damage for any damage area.

These are important considerations in designing a tsunami evacuation building, material and location, and assessing the damages for other cities in danger of future tsunami attach.

In conclusion, by using multiple geospatial factors of topographic elevation, relation to tsunami direction, coastal proximity, and coastal shape incorporated by the AHP, an appropriate pair-wise comparison of AHP is proposed to construct a weighting scheme for the geospatial factors and assessing tsunami damage. However, the damage is not only controlled by the tsunami height which is dependent highly to coastal topography, but also highly dependent on the building materials. By knowing the material behavior of different materials for each inundation depth, as shown graphically in this study, one can assess with a good precision the amount of damage. We proposed using the illustrated figures of damage for different building materials due to different inundation depths in this paper, together with GIS which produces a damage map as a powerful approach to assess the damages on buildings for an area attacked by tsunami storms.

Our research can be employed to evaluate building damage located in vulnerable areas due to tsunami hazard in future natural disasters.

\section{Acknowledgements}

The technical and financial supports by Research Center for Urban Safety and Security (RCUSS) of Kobe University and Shahid Beheshti University are gratefully acknowledged. Authors are thankful to the GSI for providing DEM data and vector maps of the study area and 2011 Tohoku Earthquake Tsunami Joint Survey for the survey data in the study area.

\section{References}

[1] National Police Agency (2011) Damage Condition of the 2011 Earthquake off the Pacific Coast of Tohoku. http://www.npa.go.jp/archive/keibi/biki/higaijokyo.pdf

[2] Ciurean, R.L., Schröter, D. and Glade, T. (2013) Conceptual Frameworks of Vulnerability Assessments for Natural Disasters Reduction. In: Tiefenbacher, J., Ed., Approaches to Disaster Management-Examining the Implications of Hazards, Emergencies and Disasters, InTech, Rijeka, 1-32.

[3] Cardona, O.-D. and van Aalst, M.K. (2012) Determinants of Risk: Exposure and Vulnerability. Cambridge University Press, Cambridge, UK and New York, 65-108. http://dx.doi.org/10.1017/cbo9781139177245.005

[4] Matsuoka, M. and Yamazaki, F. (2004) Use of Satellite SAR Intensity Imagery for Detecting Building Areas Damaged Due to Earthquakes. Earthquake Spectra, 20, 975-994. http://dx.doi.org/10.1193/1.1774182

[5] Gokon, H., Koshimura, S., Matsuoka, M. and Namegaya, Y. (2011) Developing Tsunami Fragility Curves Due to the 2009 Tsunami Disaster in American Samoa. Proceedings of Coastal Engineering Conference, Japan Society of Civil Engineers, Morioka, 9-11 November 2011, I_1321-I_1325. http://dx.doi.org/10.2208/kaigan.67.i_1321

[6] Ruangrassamee, A., Yanagisawa, H., Foytong, P., Lukkunaprasit, P., Koshimura, S. and Imamura, F. (2006) Investigation of Tsunami-Induced Damage and Fragility of Buildings in Thailand after the December 2004 Indian Ocean Tsunami. Earthquake Spectra, 22, 377-401. http://dx.doi.org/10.1193/1.2208088

[7] Arikawa, T. (2009) Structural Behavior under Impulsive Tsunami Loading. Journal of Disaster Research, 4, 377-381.

[8] Dominey-Howes, D. and Papathoma, M. (2007) Validating the "Papathoma Tsunami Vulnerability Assessment Model” (PTVAM) Using Field Data from the 2004 Indian Ocean Tsunami. Natural Hazards, 40, 113-136. http://dx.doi.org/10.1007/s11069-006-0007-9

[9] Matsutomi, H. and Harada, K. (2010) Tsunami-Trace Distribution around Building and Its Practical Use. Proceedings 
of the 3rd International Tsunami Field Symposium, Sendai, 10-11 April 2010, Session 3-2.

[10] Matsutomi, H. and Shuto, N. (1994) Tsunami Inundation Depth, Current Velocity and Damage to Houses. Proceedings of Coastal Engineering Conference, 41, 246-250.

[11] Suppasri, A., Koshimura, S., Imai, K., Mas, E., Gokon, H., Muhari, A. and Imamura, F. (2012) Field Survey and Damage Characteristic of the 2011 Tohoku Tsunami in Miyagi Prefecture. Coastal Engineering Journal, 54, 1250005. http://dx.doi.org/10.1142/S0578563412500052

[12] Suppasri, A., Koshimura, S., Matsuoka, M., Gokon, H. and Kamthonkiat, D. (2012) Application of Remote Sensing for Tsunami Disaster. In: Chemin, Y., Ed., Remote Sensing of Planet Earth, InTech, Rijeka, 143-168. http://dx.doi.org/10.5772/32136

[13] Suppasri, A., Mas, E., Koshimura, S., Imai, K., Harada, K. and Imamura, F. (2012) Developing Tsunami Fragility Curves from the Surveyed Data of the 2011 Great East Japan Tsunami in Sendai and Ishinomaki Plains. Coastal Engineering Journal, 54, 1250008. http://dx.doi.org/10.1142/S0578563412500088

[14] Suppasri, A., Imai, K., Imamura, F. and Koshimura, S. (2012) Comparison of Casualty and Building Damage between Sanrikuria Coast and Sendai Plain Coast Based on the 2011 Great East Japan Tsunami. Proceedings of International Sessions in Coastal Engineering, JSCE, 3, 76-80.

[15] Porter, K., Kennedy, R. and Bachman, R. (2007) Creating Fragility Functions for Performance-Based Earthquake Engineering. Earthquake Spectra, 23, 471-489. http://dx.doi.org/10.1193/1.2720892

[16] Reese, S., Cousins, W.J., Power, W.L., Palmer, N.G., Tejakusuma, I.G. and Nugrahadi, S. (2007) Tsunami Vulnerability of Buildings and People in South Java-Field Observations after the July 2006 Java Tsunami. Natural Hazards and Earth System Sciences, 7, 573-589. http://dx.doi.org/10.5194/nhess-7-573-2007

[17] Department of Regional Development and Environment Executive Secretariat for Economic and Social Affairs Organization of American States (1991) Primer on Natural Hazard Management in Integrated Regional Development Planning. Washington DC.

[18] Carver, S.J. (1991) Integrating Multi-Criteria Evaluation with Geographical Information Systems. International Journal of Geographical Information Systems, 5, 321-339. http://dx.doi.org/10.1080/02693799108927858

[19] Sambah, A.B. (2014) Tsunami Vulnerability Assessment Using Integrative Remote Sensing and GIS Approaches. Department of Environmental Science and Engineering Graduate School of Science and Engineering, Yamaguchi University, Yamaguchi.

[20] Schaften, F.G. (2010) Assessing Building Vulnerability to Tsunami Hazard Using Integrative Remote Sensing and GIS Approaches. Dissertation Thesis, LMU München, Fakultät für Geowissenschaften.

[21] Dall’Osso, F., Gonella, M., Gabbianelli, G., Withycombe, G. and Dominey-Howes, D. (2009) A Revised (PTVA) Model for Assessing the Vulnerability of Buildings to Tsunami Damage. Natural Hazards and Earth System Sciences, 9, 1557-1565. http://dx.doi.org/10.5194/nhess-9-1557-2009

[22] Saaty, T.L. (2008) Decision Making with the Analytic Hierarchy Process. International Journal of Services Sciences, 1, 83-98. http://dx.doi.org/10.1504/IJSSCI.2008.017590

[23] Saaty, T.L. (1977) A Scaling Method for Priorities in Hierarchical Structures. Journal of Mathematical Psychology, 15, 234-281. http://dx.doi.org/10.1016/0022-2496(77)90033-5

[24] Teknomo, K. (2006) Analytic Hierarchy Process (AHP).

[25] Saaty, T.L. (2003) Decision Aiding Decision-Making with the AHP: Why Is the Principal Eigenvector Necessary. European Journal of Operational Research, 145, 85-91. http://dx.doi.org/10.1016/S0377-2217(02)00227-8

[26] Proceedings of the 6th European Conference on Management Leadership and Governance, Wroclaw, 28-29 October 2010.

[27] Geospatial Authority of Japan (GSI), Map of Inundation Area Due to the 2011 Great East Japan Earthquake, Map number 12. Accessed on 2 November 2015. http://www.gsi.go.jp/common/000059847.pdf

[28] Drobne, S. and Lisec, A. (2009) Multi-Attribute Decision Analysis in GIS: Weighted Linear Combination and Ordered Weighted Averaging. Informatica, 33, 459-474.

[29] Suppasri, A., Mas, E., Charvet, I., Gunasekera, R., Imai, K., Fukutani, Y., Abe, Y. and Imamura, F. (2013) Building Damage Characteristics Based on Surveyed Data and Fragility Curves of the 2011 Great East Japan Tsunami. Natural Hazards, 66, 319-341. http://dx.doi.org/10.1007/s11069-012-0487-8

[30] Cadell, W. (2002) Report on the Generation and Analysis of DEMs for Spatial Modeling. 11-15.

[31] Weih Jr., R.C. and Mattson, T.L. (2004) Modeling Slope in a Geographic Information System. Journal of the Arkansas Academy of Science, 58, 100-108.

[32] Sinaga, T.P.T., Nugroho, A., Lee, Y.-W. and Suh, Y. (2011) GIS Mapping of Tsunami Vulnerability: Case Study of 
the Jembrana Regency in Bali, Indonesia. KSCE Journal of Civil Engineering, 15, 537-543. http://dx.doi.org/10.1007/s12205-011-0741-8

[33] Tanaka, H., Kayane, K., Adityawan, M.B. and Farid, M. (2013) The Effect of Bed Slope to the Tsunami Intrusion into Rivers. Coastal Dynamics, 1601-1610.

[34] Yeh, H., Tolkova, E., Jay, D., Talke, S. and Fritz, H. (2012) Tsunami Hydrodynamics in the Columbia River. Journal of Disaster Research, 7, 604-605.

[35] Adityawan, M.B., Roh, M., Tanaka, H. and Farid, M. (2012) The Effect of River Mouth Morphological Features on Tsunami Intrusion. pp. 75-83.

[36] Fukui, T. (2012) Considering the Extent of Damage in Ishinomaki from a Civil Engineering Perspective. Disaster, Infrastructure and Society: Learning from the 2011 Earthquake in Japan, No. 2, 14-21. http://hdl.handle.net/10086/23128

[37] Shank, M. (2008) Using Remote Sensing to Map Vegetation Density on a Reclaimed Surface Mine.

[38] Normalised Difference Vegetation Index (NDVI), NDVI: A Non-Technical Overview, 2002. http://www.pvts.net/pdfs/ndvi/3_3_ndvi.PDF

[39] Singh, S.K., Chandel, V., Kumar, H. and Gupta, H. (2014) RS \& GIS Based Urban Land Use Change and Site Suitability Analysis for Future Urban Expansion of Parwanoo Planning Area, Solan, Himachal Pradesh (India). International Journal of Development Research, 4, 1491-1503.

[40] Rao, R.V. (2013) Decision Making in the Manufacturing Environment Using Graph Theory and Fuzzy Multiple Attribute Decision Making Methods, Chapter 2 Improved Multiple Attribute Decision Making Methods. http://www.springer.com/978-1-4471-4374-1 http://dx.doi.org/10.1007/978-1-4471-4375-8

[41] Tanimoto, K. (1983) On the Hydraulic Aspects of Tsunami Breakwaters in Japan. Proceedings of the International Tsunami Symposium by IUGG Tsunami Commission, 1981 Sendai-Ofunato-Kamaishi, Japan, 423-435. http://dx.doi.org/10.1007/978-94-009-7172-1_32 